\title{
Evaluation of the properties and storage stability of EVA polymer modified asphalt
}

\author{
Eman I. Mjthab Adil K. Hussien Niám M. Al-Layla \\ Department of Chemistry / College of Science \\ University of Mosul
}

Received

13 / 05 / 2010
Accepted

07 / 07 / 2010

\begin{abstract}
الملخص
أصبحت البوليمرات تستعمل لتحوير المادة الاسفلتية بشكل متزايد وذلك لدورها في

تحسين مواصفات اسفلت التبليط للطرق السريعة ـ تمّ في هذا البحث معالجة نوعين من الاسفلت

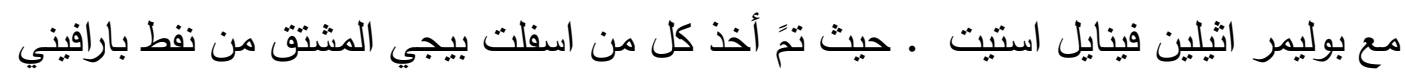

الأساس واسفلت قيارة المشتق من نفط اروماتي الأساس ومعالجتهما مع نسب مختلفة من بوليمر

اثيلين فينايل استيت، وقد اخضعت النماذج المحضرة لقياس درجة الليونة والنفاذية والاستطالة

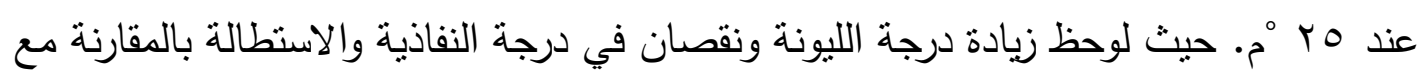

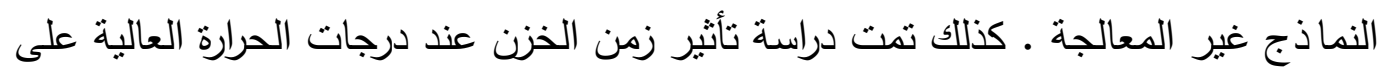
التوافق بين الاسفلت والبوليمر •
\end{abstract}

\begin{abstract}
Polymers are being increasingly used for modification of Asphalt to enhance highway pavement performance. This paper describes the polymer modification of two penetration grade Asphalt with ethylene vinyl acetate (EVA). Two base asphalt from two crude oil sources (Baiji paraffinic asphalt \& Qaiyarah aromatic asphalt) were mixed with ethylene vinyl acetate (EVA) at different polymer content. The physical properties including softening point, penetration at $25^{\circ} \mathrm{C}$, and ductility of the basic asphalt and ethylene vinyl acetate modified asphalt were studied. It has been observed that the softening point has increased on the other hand, the penetration and ductility values has decreased according to the test results. The effect of storage time on uniformity at higher temperature was studied by storage stability test .
\end{abstract}

Keyword: polymer modified asphalt; phase separation; EVA copolymer; storage stability. 


\section{Introduction}

Asphalt is a natural derivative of distillation of crude oil, which is particularly suitable as a binder for road construction. At room temperature Asphalt is a flexible material with a density of $1 \mathrm{gm} / \mathrm{cm}^{3}$, but at low temperatures it becomes brittle and at high temperatures is flows like a viscous liquid. The physical, mechanical and rheological properties of the Asphalt depend basically on its colloidal structure, linked to the chemical composition, in particular, to the proportion of asphaltenes and maltenes. Asphaltense are polar materials of high molecular weight (10.000 to 100.000), which are insoluble in n-heptane and constitute between $5 \%$ and $25 \%$ of the Asphalt. On the other hand, maltenes are constituted by resins, and aromatic and saturate oils that are soluble in nheptane and posses lower molecular weight.[1, 2]

According to some authors, there is a relationship between the asphaltene content and physical properties, such as viscosity, penetration, softening point, etc. [3]

The use of synthetic polymers for the modification of asphalt binder dates back to the early 1970 [4], with these binders, subsequently having decreased temperature susceptibility, increased cohesion and modified rheological characteristic $[5,6]$. The most commonly used additives are copolymers, such as SBS, EVA, ...etc.

The wide use of this type of polymer for modification is due to their thermoplastic nature at higher temperatures and their ability to form networks upon cooling. It has been shown [7,8] that rheological properties may change dramatically by modification of the base asphalt by these types of polymers.

\section{Experimental}

\subsection{Materials:}

Two base Asphalt (A and B) were used to produce a number of Laboratory Asphalt - EVA blends.

The Asphalt A is obtained from Baiji refinery (Iraq) that derived from Kirkuk paraffinic crude oil. But the Asphalt B is obtained from Qaiyarah refinery (Iraq) that derived from Qaiyarah aromatic (nonparaffinic) crude oil. Table 1 lists the physical properties of this asphalt $(\mathrm{A}, \mathrm{B})$.

EVA copolymer available as pellets 2 to $3 \mathrm{~mm}$ in diameter (vinyl acetate content $=19 \%$ ) supplied by special material trading limited Co.

The EVA copolymers are thermoplastic materials formed by copolymerization of ethylene and vinyl acetate. Their characteristics lie between those of low-density polyethylene, a semirigid and translucent product and those of a transparent and rubbery material similar to plasticised PVC and certain rubbers. 


\subsection{Preparation of samples and measurement of physical properties.}

Three hundred grams of the asphalt were heated to fluid condition and poured into a $1000 \mathrm{ml}$ spherical flask, which was then placed in a heating mantle. Upon reaching $165{ }^{\circ} \mathrm{C}$ a required amount of EVA copolymer $(2 \%, 4 \%, 6 \%, 8 \%, 10 \%$, and $12 \%$ by asphalt weight) was added to the asphalt (slowly, to prevent the polymer particles from possible agglomeration). Mixing was performed using mechanical mixer $(250 \mathrm{rpm})$ for 5 minutes, after which the speed was lowered to $150 \mathrm{rpm}$. Mixing was continued for $3 \mathrm{~h}$.

When blended was completed, the individual modified blends were divided for testing to penetration at $25{ }^{\circ} \mathrm{C}$, softening point, ductility at $25^{\circ} \mathrm{C}$ according to ASTM D5, ASTM D36 and ASTM D113, respectively.

\subsection{Storage Stability Test.}

The storage stability for modified and unmodified asphalts was measured according to ASTM D 5892-96a: each sample was put into the glass tube $32 \mathrm{~mm}$ in diameter and $150 \mathrm{~mm}$ in height.

vertically

After closing the tube by silicon Rubber stopper, it was stored $163{ }^{\circ} \mathrm{C}$ in an oven for $48 \mathrm{~h}$, then the tube was cooled to room temperature and cut the tube with a glasscutter transversely into three equal parts.

The upper and lower parts were melted and tested to softening point, if the difference between top and bottom softening temperature is less than $2.5^{\circ} \mathrm{C}$ the blend is considered as good storage stability modified asphalt binder and string is not required up to $48 \mathrm{~h}$ storage [9].

\section{Results and Discussion}

\subsection{Effect of EVA content}

Polymer modification has significantly enhanced the rheological (physical) properties of asphalt. Viscous and elastic properties of modified asphalt increased with the increase of polymer content.

The effect of EVA polymer modification on the conventional binder properties of the two polymer modified asphalt groups can be seen in table 2; Figs. 1, 2 and 3. As a decrease in penetration and ductility and an increase in softening point with increasing polymer content, because additive polymer due to increasing molecular weight of asphalt. The rate of change of penetration and softening point gradually decreases as the polymer concentration is increased.

\section{2 storage stability of EVA modified asphalts}

Due to the difference in the solubility parameter and density between EVA and asphalt, phase separation would take place in EVA modified asphalts during storage at elevated temperatures. 
By comparing the results from fig. 4 it seems that the storage stability of EVA modified asphalt (Qaiyarah) is better than EVA modified asphalt (Baiji) specialize at $(2,4,6 \%$ EVA) because Qaiyarah asphalt was found to contain $9.25 \%(\mathrm{w} / \mathrm{w})$ sulfur with respect to total asphalt in crude oil [10]. It is commonly believed that sulfur chemically crosslinks the polymer molecules and chemically couples polymer and asphalt through sulfide and / or polysulfide bonds [11].

We can seen also that the softening point of bottom section is higher than those of the upper section for some samples $(8,10,12 \%$ EVA). This proved that the crosslinking and chemical bonds that formed by sulfur are destroyed at high content EVA polymer [12].

\section{Conclusions}

The environmental variations, especially between summer and winter and between day and night, are greatly affecting the durability of pavement's asphalt.

EVA was one of the first polymers to be used successfully in asphalt applications. It essentially stiffens the binder and thereby makes the asphalt more resistant to traffic loading and rutting, particularly at higher road temperatures during hot summers when asphalt surfaces are at higher risk of softening and rutting under traffic.

The data presented on the modified asphalt binder show that very good stability results are obtained for blends containing 2\% EVA of both asphalts: No phase separation is detected after 2 days.

\section{References :}

(1) Read, J. (1998). Chem Brit; 34 (8): 46-9.

(2) Corbett, LW. (1969). Composition of asphalt based on generic fractionation using solvent deasphaltening, elution-adsorption chromatography, and densimetric characterization. Anal Chem; 41: 576-9.

(3) Dealy, JM. (1979). Rheological properties of oil sand bitumens. Can. J. Chem. Eng; 57: 677-83.

(4) Ajour, AM. (1981). Several projects, several types of surfaces. Bull LCPC; 113: 9-21.

(5) Brule, B., Brion, Y., Tanguy, A. (1988). Paving asphalt polymer blends; relationship between composition, structure and properties. Proc. Assoc Asphalt Paving Technologists; 57 : 41-64.

(6) King, GN., King, HW., Charerot, P., Planche, JP., Harders, O. (1993). Using European wheel. Uracking and restrained tensile teste to avlidate SHRP performance graded binder specification for polymer modified asphalt proc fifth eurobitume Congress, Stockholm; LA (1.06): 51-5. 
(7) Collins, J. H., Bouldin, M. G., Gelles, R. and Berker, A. (1991). Proceeding of the Association of Asphalt paving Technologists, 60, 43-79.

(8) Valkering, C. P., Vonk, W. C. And Whiteoak, C. D. (1992). Shell Bitumen Review, 66, 9-11.

(9) Jin, H. G. G., Zhang, Y., Zhang, K., Sun and Fan, Y. (2002). Improved properties of polystyrene modified asphalt through dynamic vulcanization, polymer testing, 21: 633-640.

(10) Tawfiq, K. S., (1991). Studies on the nature of catalyzed reaction between suffer and Bitumen, Ph.D. Thesis, College of Sci. Mosul University.

(11) Guian, W., Yong, Z., Yinxi, Z., Kang, S. and Yongzhong, F. (2002). Rhoological characterization of storage - stable SBS modified asphalts, polymer testing, 21: 295-302.

(12) Ghaly, N. F., (2008). Effect of sulfur on the storage stability of tire rubber modified asphalt. World Journal of Chemistry, 3 (2): 42-50.

Table 1. Convention of physical properties of the base Asphalts

\begin{tabular}{|c|c|c|c|c|}
\hline Asphalt & $\begin{array}{c}\text { Penetration } \\
\mathbf{2 5}^{\mathbf{}} \mathbf{C}(\mathbf{m m})\end{array}$ & $\begin{array}{c}\text { Softening } \\
\left.\text { Point } \mathbf{(}^{\mathbf{}} \mathbf{C}\right)\end{array}$ & $\begin{array}{c}\text { Ductility 25} \mathbf{2}^{\mathbf{C}} \mathbf{C} \\
(\mathbf{c m})\end{array}$ & $\begin{array}{c}\text { Asphaltenes } \\
\text { Content \% }\end{array}$ \\
\hline \hline A & 20 & 54 & +100 & 12.3 \\
\hline B & 55 & 53 & 21 & 36.2 \\
\hline
\end{tabular}

Table 2. Changes in physical properties of binder at different EVA concentrations.

\begin{tabular}{|l|c|c|c||}
\hline \multicolumn{1}{|c|}{ Binder } & $\begin{array}{c}\text { Softening } \\
\text { point }^{\mathbf{}} \mathbf{C}\end{array}$ & $\begin{array}{c}\text { Penetration } \\
\mathbf{m m} \mathbf{2 5}^{\mathbf{}} \mathbf{C}\end{array}$ & $\begin{array}{c}\text { Ductility } \mathbf{~ c m}, \mid \\
\mathbf{2 5}^{\mathbf{}} \mathbf{C}\end{array}$ \\
\hline \hline Asphalt A & 54 & 20 & 100 \\
\hline Asphalt A +2\% EVA & 55 & 19.2 & 89.0 \\
\hline Asphalt A +4\% EVA & 59 & 17.6 & 63.0 \\
\hline Asphalt A +6\% EVA & 63 & 14.3 & 38.5 \\
\hline Asphalt A +8\% EVA & 65 & 13.3 & 20.0 \\
\hline Asphalt A +10\% EVA & 67 & 11.3 & 20.0 \\
\hline Asphalt A +12\% EVA & 69 & 9.5 & 8.5 \\
\hline Asphalt B & 53 & 55.0 & 21.0 \\
\hline Asphalt B +2\% EVA & 60 & 36.0 & 21.0 \\
\hline Asphalt B +4\% EVA & 62 & 33.6 & 19.0 \\
\hline Asphalt B +6\% EVA & 65 & 29.0 & 12.5 \\
\hline Asphalt B +8\% EVA & 69 & 28.3 & 11.5 \\
\hline Asphalt B +10\% EVA & 73 & 25.6 & 7.5 \\
\hline Asphalt B +12\% EVA & 73 & 21.3 & 7.5 \\
\hline
\end{tabular}


Evaluation of the properties and storage stability of EVA polymer modified ...

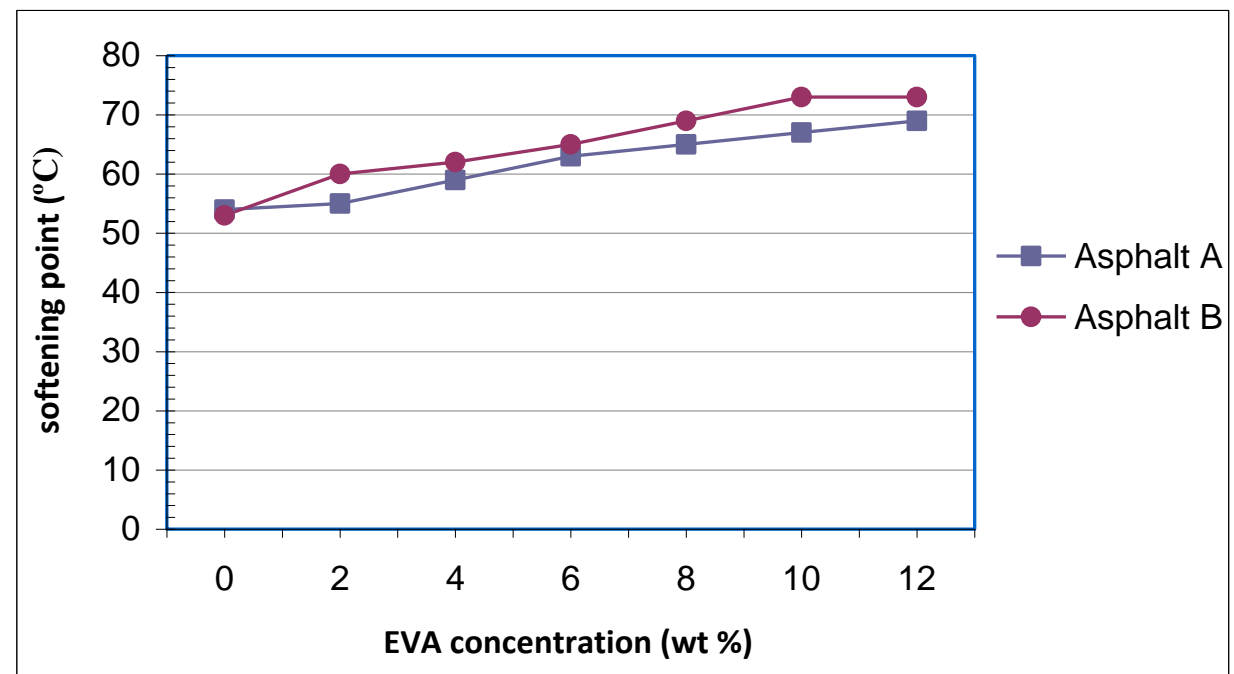

Fig. 1: change in softening point of asphalt A \& B at different EVA concentration.

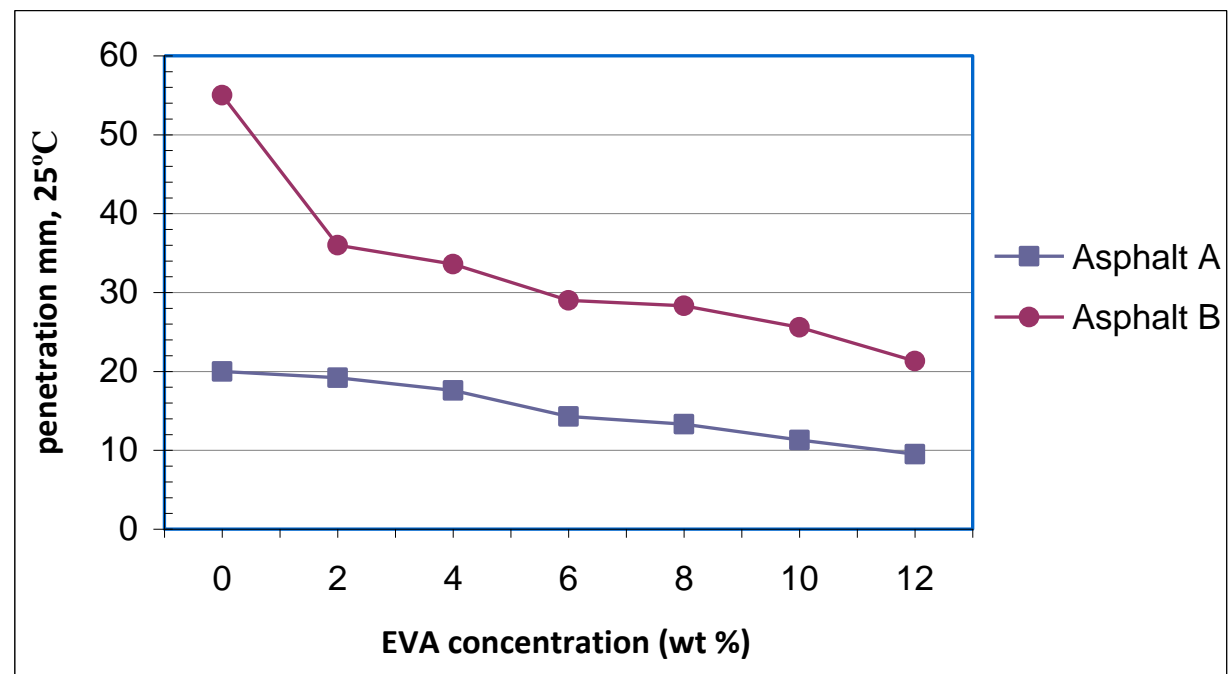

Fig. 2: change in penetration of asphalt A \& B at different EVA concentration.

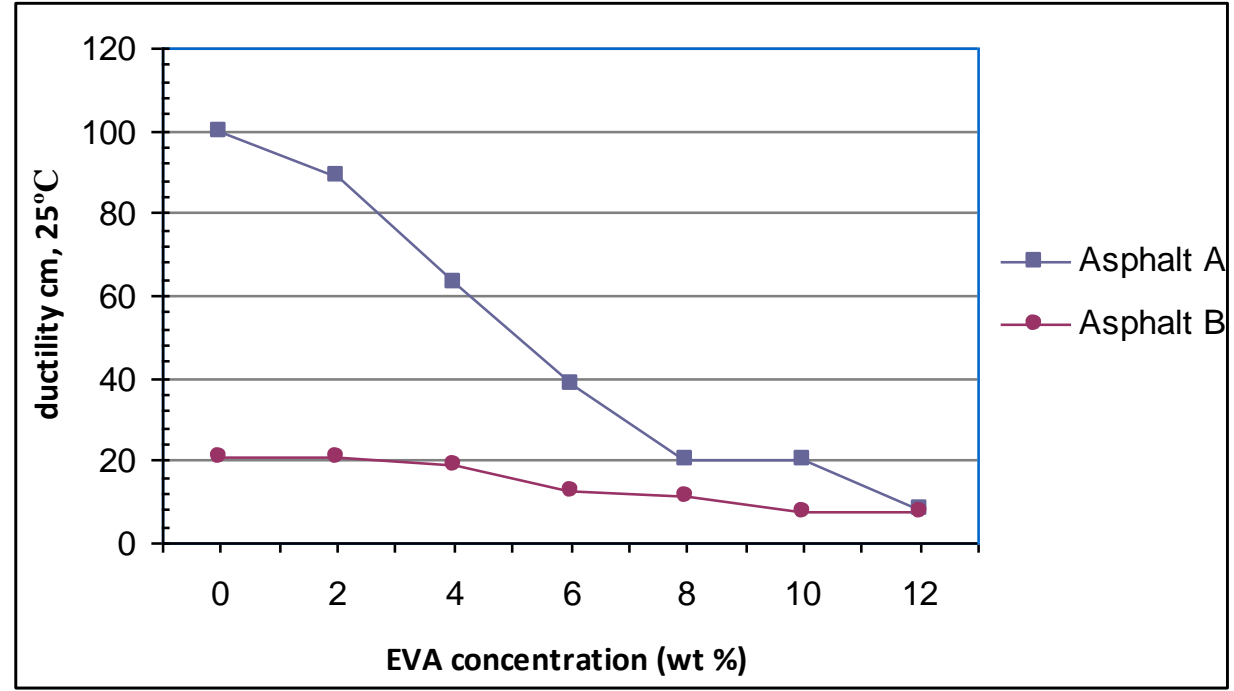

Fig. 3: change in ductility of asphalt A \& B at different EVA concentration. 
Eman I. Mjthab \& Adil K. Hussien \& Niám M. Al-Layla

(A):

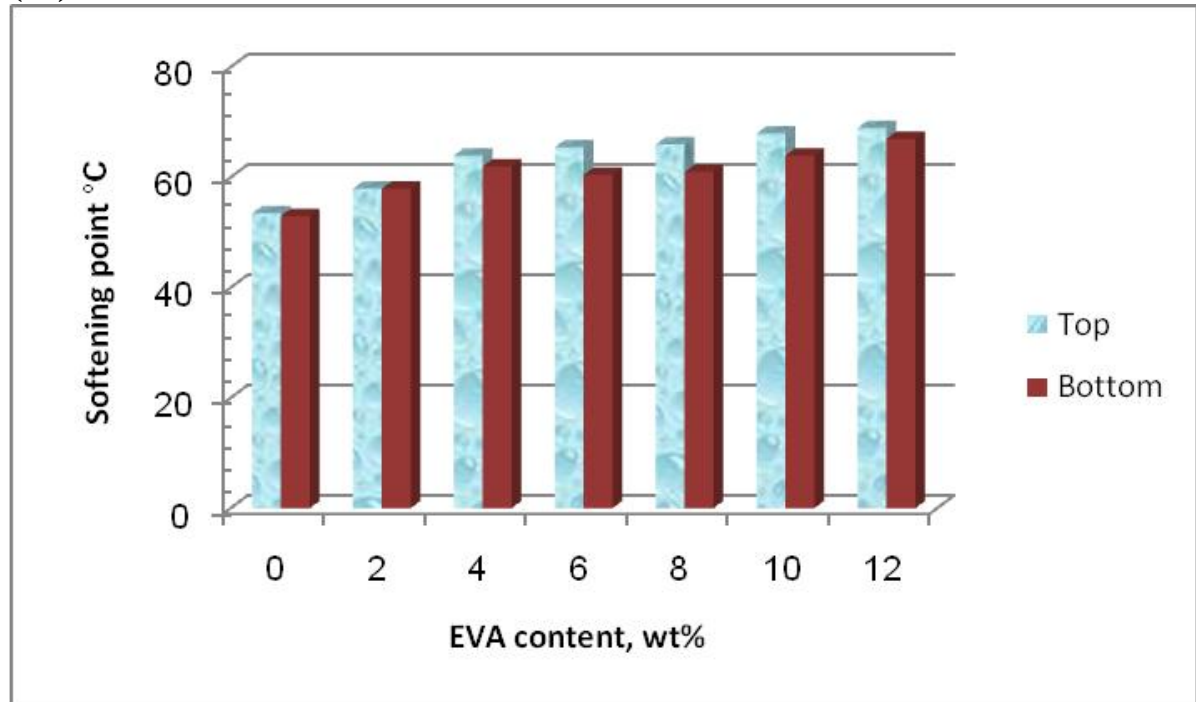

(B):

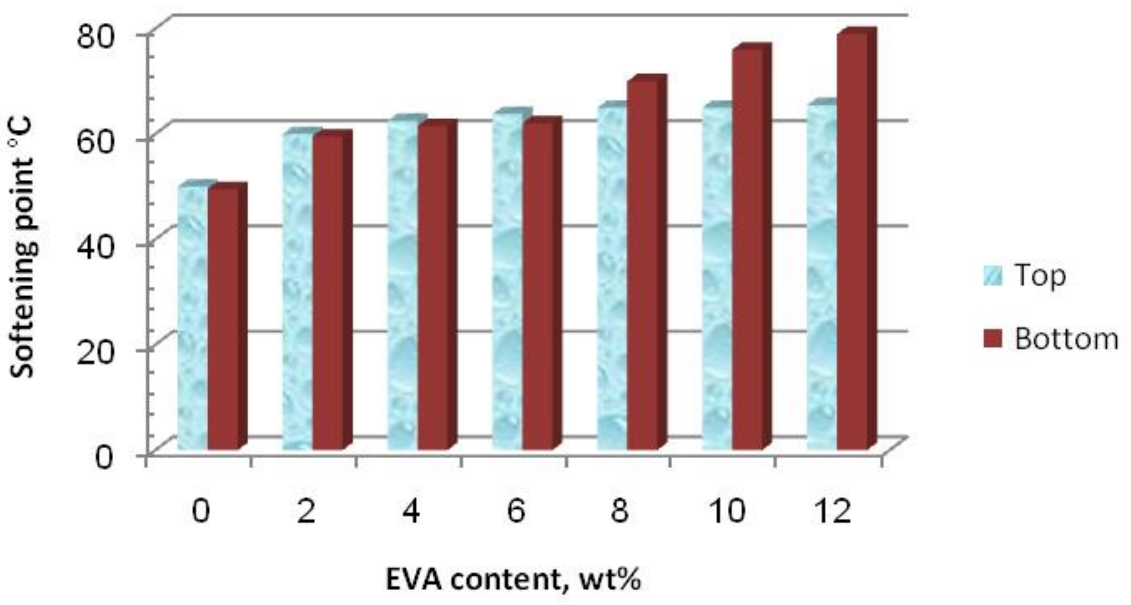

Fig. 4: Effect of EVA copolymer on storage stability of two base asphalt (Baiji \& Qaiyarah) 